\section{Overview of the USDA Mid-Atlantic Regional Wetland Conservation Effects Assessment Project}

\author{
S. Lee, G.W. McCarty, M.W. Lang, and X. Li
}

\begin{abstract}
This paper provides an overview of studies conducted under the USDA MidAtlantic Regional Wetland Conservation Effects Assessment Project (MIAR study). Under the MIAR effort, numerous studies were conducted to (1) quantify ecosystem functions provided by restored wetlands by comparing functions within depressional nontidal wetlands with a varying degree of alteration (i.e., natural wetlands, restored wetlands, and prior converted croplands [PCCs]) and (2) develop tools for wetland monitoring and assessment We present these studies after classifying them according to wetland functional (biodiversity, biogeochemical, and hydrologic) and tool development categories (remote sensing, hydrologic modeling, and geospatial analysis). Furthermore, we provide lessons from the MIAR study's findings for enhanced wetland conservation practices. Our overview demonstrates that restoration of wetlands contributes to enhancing wetland biodiversity, biogeochemical, and hydrologic functions in the Mid-Atlantic Region. Wetland monitoring tools that were developed as part of this study aid our understanding of wetland functions and the effect of restoration on those functions. Findings from these studies suggest that it is important to (1) establish long-term restoration plans; (2) minimize soil compaction during restoration; (3) increase wetland water storage capacity; (4) locate restored wetlands around natural wetlands to magnify restoration effects and improve water quality management; (5) consider the importance of shallow water and topography for supporting native plant species; (6) use landscape parameters for targeting and implementing restoration efforts; and (7) use wetland monitoring tools for precision management. This MIAR study provides scientific data to support wetland restoration activities and guidelines to foster the restoration of wetland-mediated ecosystem services.
\end{abstract}

Key words: MIAR study-prior converted croplands-restoration-wetlands-wetland functions

\begin{abstract}
Wetlands are at high risk for degradation or loss due to geomorphic and hydrologic alterations, pollutant loads, invasive species, climate change, and development (Zedler and Kercher 2005; Cvetkovic and Chow-Fraser 2011) despite their well-recognized hydrologic, biogeochemical, and ecological benefits (Bullock and Acreman 2003; Fisher and Acreman 2004; Meli et al. 2014). Coastal wetlands are most vulnerable to degradation or loss (Barbier 2013). Increased acknowledgement of environmental deterioration
\end{abstract}

resulting from wetland loss has led to wetland restoration across the world (Zhao et al. 2016) These restoration efforts become increasingly important due to disproportional impacts of restored wetlands on surrounding ecosystems (Meli et al. 2014).

The USDA Mid-Atlantic Regional Wetland Conservation Effects Assessment Project (i.e., the MIAR study) is one of seven USDA Conservation Effects Assessment Project Wetland Component investigations that aim at assessing the effects and effectiveness of wetland restoration conducted under multiple USDA easement programs. The Mid-Atlantic region (MIAR) of the United States spans an area of about $58,000 \mathrm{~km}^{2}$ in the eastern United States, including areas of the Atlantic Coastal Plain physiographic province located in five states (New Jersey, Maryland, Delaware, Virginia, and North Carolina; figure 1). Wetlands are abundant in this region, but practices associated with agriculture, silviculture, urbanization, sea level rise, and other causes have resulted in substantial wetlands loss (Lang et al. 2015b).

To best demonstrate the effects of wetland restoration on wetland-meditated ecosystem services, the MIAR study focused on 48 depressional nontidal wetlands with a varying degree of alteration: 14 natural and 18 restored wetlands as well as 16 prior converted croplands (PCCs). These wetlands were randomly selected to meet the following conditions: (1) landowners were willing to participate in the MIAR study, (2) wetlands were relatively near to other wetlands that represent the complete alteration gradient, and (3) wetlands were typical for the MIAR.

Natural wetlands were defined as wetlands with native plant species (e.g., sweetgum [Liquidambar styraciflua], red maple [Acer rubrum], summersweet [Clethra alnifolia], and roundleaf greenbriar [Smilax rotundifolia]) and minimal hydrologic disturbance. Natural wetlands were used to represent the baseline condition and thus they allowed the evaluation of restoration effectiveness relative to the stated goal of the USDA Natural Resources Conservation Service Wetland Restoration (657) Practice, which is to "restore wetland function, value, habitat, diversity and capacity to a close approximation of the pre-disturbance condition" (USDA NRCS 2010).

Restored wetlands were hydrologically restored between 2001 and 2008 via multiple USDA conservation programs, including the Agricultural Conservation Easement Program and the Conservation Reserve

Sanghcul Lee is an assistant professor with the School of Environmental Engineering, University of Seoul, Dongdaemun-gu, Seoul, South Korea. Gregory W. McCarty is a research soil scientist USDA Agricultural Research Service (ARS), Hydrology and Remote Sensing Laboratory, Beltsville, Maryland. Megan W. Lang is the chief scientist, National Wetlands Inventory, US Fish and Wildlife Service, Falls Church, Virginia. Xia Li is a postdoctoral associate, USDA ARS, Hydrology and Remote Sensing Laboratory, Beltsville, Maryland. 


\section{Figure 1}

USDA Mid-Atlantic Regional Wetland Conservation Effects Assessment Project (MIAR) study site locations, identified by state. Wetland types (natural wetlands:restored wetlands: prior converted cropland) by states are 1:3:3 (Delaware), 3:3:3 (North Carolina), 3:4:4 (Virginia), and 7:8:6 (Maryland).

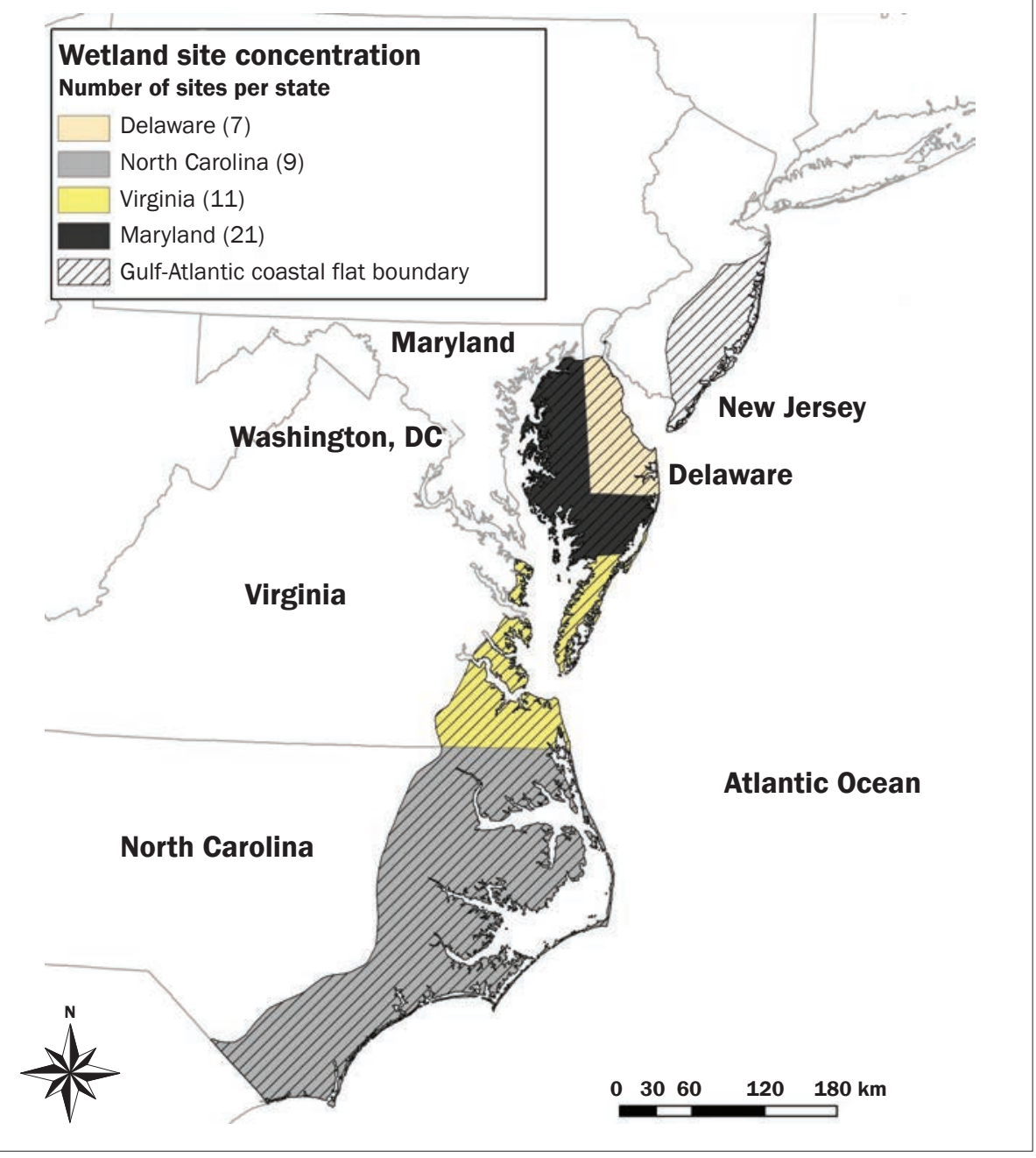

Program. Before restoration, restored wetlands were drained croplands for cultivating row crops, primary corn (Zea mays) or soybeans (Glycine max). Restoration often requires a combination of techniques, including the plugging of ditches, creation of berms, excavation (removal of soil to form a depression), and perhaps soil compaction to aid in establishment of wetland hydrology. As a part of restorations, wetland vegetation was generally not planted although trees were planted within some upland buffer zones. PCCs are defined as croplands converted from wetlands before 1985 that have been under crop cultivation during most years since that time.

Over the past 10 years, numerous studies have been performed to support the MIAR study. The key topics of those stud-

\section{Materials and Methods}

In this overview, we review 34 previous published studies supported by the MIAR study (table 1). In addition to 48 core wetlands, ancillary wetlands were examined or landscape-level studies were performed depending on the goals of individual studies. To summarize a wide range of scientific findings, we group those studies by three wetland functional and tool development categories. Wetland functions explored in the MIAR study include biodiversity, biochemical, and hydrologic functions (table 2). To provide insight on the trajectory of restored wetlands, we indicate whether restored wetlands were found to be more similar to natural wetlands or PCC endpoints, or neither endpoint (i.e., none). Furthermore, we indicate whether restored wetlands contribute to improving three wetland functions regardless of their trajectory based on conclusive statements in individual papers. These indications are made only for studies with explicit comparisons of restored wetlands with natural wetlands/ PCCs. The studies that were not designed to test or did not provide indication of improved ecosystem function were classified as "no" contribution. Under the MIAR study, three tools (i.e., remote sensing, geospatial analysis, and hydrologic modeling) were either tested and further developed (table 1). These tool development studies and their contributions are introduced in this overview. A few studies covered multiple topics that overlapped different subcategories.

Biodiversity Function Comparison. Studies that explored biodiversity functions commonly used index-based comparisons to quantify differences among the three wetland types. We considered all indices reported in those studies for comparison. Although a common index was used in multiple studies, all indices were treated as independent indicators because the same index can show different wetland conditions by individual studies depending on the number of sampling sites, data collection methods, and sampling timing. To efficiently compare multiple results from different studies, the individual index values were converted to rank scores ranging from 1 to 3 : low (1), medium (2), and high (3).

Biogeochemical Function Comparison. Differences in biogeochemical function were mainly revealed based on samples collected from three wetland types. Through experimental processes, those studies identified key 
Table 1

Reviewed USDA Mid-Atlantic Regional Wetland Conservation Effects Assessment Project (MIAR) publications organized by ecosystem function, tool development, wetland type studied, and spatial scale.

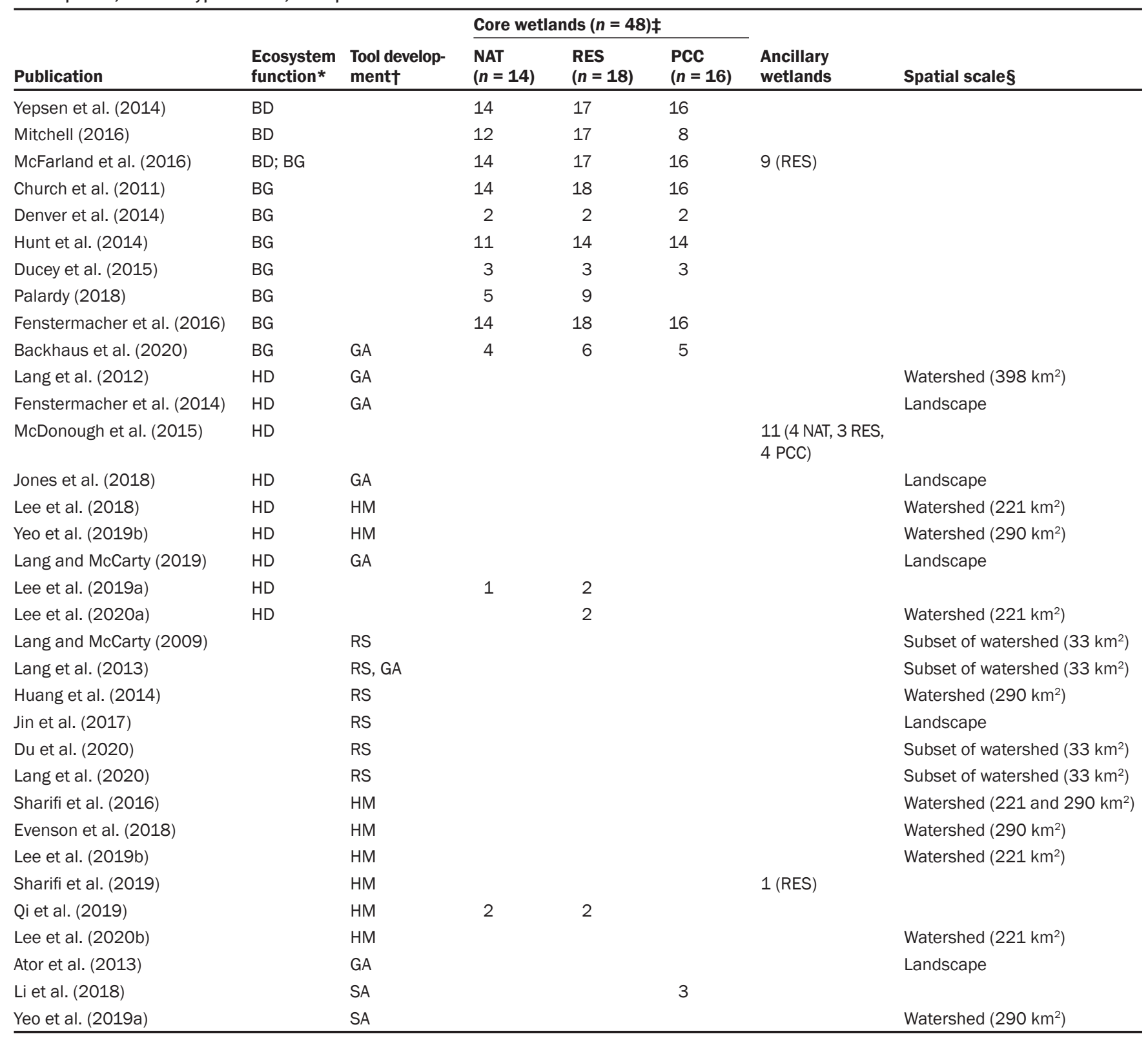

*BD, BG, and $\mathrm{HD}$ indicate biodiversity, biogeochemical, and hydrologic functions.

†RS, GA, and HM denote remote sensing, geospatial analysis, and hydrologic modeling, respectively.

‡NAT, RES, and PCC denote natural and restored wetlands, and prior converted croplands, respectively.

$\S$ Landscape indicates watershed or regional-level studies. A watershed in the spatial scale column indicates the boundary defined by hydrologic unit code (HUC).

biogeochemical variables and then made comparisons concerning the driving variables. We listed important biogeochemical variables examined in previous studies and ranked the variables on a scale from low (1) to high values (3) for comprehensive comparisons among several studies. Furthermore, we noted whether biogeochemical variables in restored wetlands were similar to natural wetlands or PCCs. Some studies compared the three wetland types based on different landscape conditions (e.g., wetness). We averaged those values across different wetness and elevations and reported the averaged values to inform general patterns across three wetland types.
Hydrologic Function Comparison. Most hydrologic function assessments were conducted at the landscape level to estimate wetland impacts on local hydrology. A few observation-based studies mostly focused on advancing our understanding of wetland hydrology based on time-series monitoring data. We reviewed key findings, 


\section{Table 2}

Three wetland functions defined in this overview.

\begin{tabular}{ll}
\hline Functions & Descriptions \\
\hline Biodiversity function & Provision of habitats for plants and animals \\
Biogeochemical function & Transformation of nitrogen, phosphorus, and carbon \\
& Removal of excess nutrients and chemical pollutants \\
& Control of greenhouse emission gases \\
Hydrologic function & Water storage \\
& Controlling water transports and downstream waters
\end{tabular}

estimated the potential hydrologic function of restored wetlands, and reported observed wetland hydrological processes. Two studies that directly compared hydrologic characteristics among three wetland types were separately discussed to show restored wetlands' hydrologic benefits relative to natural wetlands/PCCs.

Tool Development. Numerous MIAR assessments were focused on developing tools, including remote sensing, geospatial analysis, and hydrologic modeling tools. Remote sensing and geospatial analysis were employed concurrently when remote sensing-driven data were used to guide geospatial analysis. For example, a light detection and ranging (LiDAR)-based digital elevation model (DEM) was employed in geospatial analysis due to its usefulness in characterizing land surface variations. In this overview, the scope of remote sensing techniques are constrained to develop remote sensing products for wetland mapping. Studies using LiDAR-DEMs for any analyses are classified as geospatial analysis. We tabulated remote sensing products and input data for individual studies adopting remote sensing tools. The model type, development process, examined wetland functions, and spatial scale were tabulated for individual studies that used hydrologic modeling tools. Studies with geospatial analysis tools were summarized by analyzed wetland characteristics and wetland functions.

\section{Results and Discussion}

Do Restored Wetlands Support Biodiversity Function? Three studies compared plant and amphibian species using multiple indices derived from sampling data (table 3). Twelve and one indices were calculated for plant and amphibian species, respectively. Plant indices (e.g., woody species, native species, tree biomass, tree species diversity, Coefficient of Conservatism, and Floristic Quality Assessment Index [FQAI]) consistently demonstrated that tree diversity and species were abundant in natural wetlands, while restored wetlands are dominated by herba- ceous species. According to species richness and Shannon Evenness Index, the highest species richness was found in restored wetlands due in part to invasive species, but native species predominately inhabited natural wetlands (Yepsen et al. 2014). Human alteration indicated by the Anthropogenic Activity Index was highest in PCCs, followed by restored and natural wetlands (table 3). PCC plant samples were not taken in McFarland et al. (2016) since there were few plants on PCCs during the sampling period (October to November of 2011). Natural wetlands were shown to have the highest amphibian species richness, but three wetland types did not indicate significant differences likely due to inadequate sampling data (Mitchell 2016). Additional assessments are needed to further explore the contribution of restored wetlands to amphibian abundance and biodiversity.

Two of three studies concluded that restored wetlands were more similar to natural wetlands and stated that restored wetlands contributed to increases in plant and amphibian diversity (McFarland et al. 2016; Mitchell 2016). Interestingly, a study by Yepsen et al. (2014) concluded that succession of restored wetlands was toward neither natural wetlands nor PCCs, but restored wetlands were found to increase plant biodiversity. Closeness to farmlands, different hydrologic conditions, and anthropogenic stressor likely disallowed restored wetlands to exhibit predisturbance conditions (e.g., natural wetlands [Yepsen et al. 2014]). Long-term monitoring is emphasized to have deep insight on the evolvement of restored wetlands since development of native species (e.g., woody species) community requires substantial time (Yepsen et al. 2014). Furthermore, restoration activities around natural wetlands can foster restoration effects due to increased effects of ecosystem services stemming from natural wetlands. Regardless of the trajectory of restored wetlands examined for biodiversity function, the three assessments agreed that restoration activities improved the biodiversity function of wetlands within the MIAR.
Do Restored Wetlands Support Biogeochemical Function? Biogeochemical functions explored in the MIAR study were examined using intensive field data collection. The key biogeochemical variables that were derived from observational data are listed in table 4 . These biogeochemical variables are either consistent or inconsistent across studies. Phosphorus (P) values (e.g., flux or percentage) in PCCs tend to be substantially greater than in restored and natural wetlands (Church et al. 2011; Hunt et al. 2014; Ducey et al. 2015; Fenstermacher et al. 2016; McFarland et al. 2016; Backhaus et al. 2020) since fertilizer application in PCCs increase the level of P. Restored wetlands often have significantly greater $\mathrm{P}$ values than natural wetlands likely due to agricultural legacy (remaining fertilizers) and a relatively short ( 10 years) restoration period (Church et al. 2011; Ducey et al. 2015; McFarland et al. 2016).

Differences in carbon (C) values among the three wetland types were fairly minimal between individual studies. Natural wetlands commonly indicate greater $\mathrm{C}$ values (e.g., flux or percentage) than restored wetlands and PCCs (Hunt et al. 2014; Palardy 2018). A high level of inundation and/or soil saturation in natural wetland limits decomposition, leading to greater $\mathrm{C}$ values relative to restored wetlands and PCCs. Measured soil moisture conditions in natural wetlands were found to be greater than the two other wetland types (Hunt et al. 2014). However, Ducey et al. (2015) reported greater C values in restored wetlands than natural wetlands and PCCs. These two studies used the similar sampling method, but their results clearly differed due to different soil properties, mineral-rich (Hunt et al. 2014) and organic-rich (Ducey et al. 2015) soils. Findings from Fenstermacher et al. (2016) agreed with Hunt et al. (2014) and Ducey et al. (2015) that $\mathrm{C}$ values varied by soil properties; for example, $\mathrm{C}$ values in natural wetlands were greater (or lower) than restored wetlands on wetlands with mineral (or organic) soils. These results informed that wetland soil properties should be taken into account to explore the effects of restored wetlands on $\mathrm{C}$ stocks. In addition, Fenstermacher et al. (2016) found that when restoration was implemented without excavation (i.e., plugging artificial drainage structures), $\mathrm{C}$ values $\left(6.1 \mathrm{~kg} \mathrm{C} \mathrm{m}^{-2}\right)$ were found to be greater than when excavation was used $\left(2.7 \mathrm{~kg} \mathrm{C} \mathrm{m} \mathrm{m}^{-2}\right)$. In addition to removing soil $\mathrm{C}$, excavation 


\section{Table 3}

List of biodiversity function publications with examined indices, ranking of biodiversity function, the trajectory of restored wetlands ("Direction"), and the indication of restored wetland contribution to biodiversity function ("Contribution") for individual publications.

\begin{tabular}{|c|c|c|c|c|c|c|}
\hline Publication & Index & NAT & RES & PCC & Direction & Contribution \\
\hline \multirow[t]{9}{*}{ Yepsen et al. (2014) } & Species richness & 2 & 3 & 1 & Toward None & Yes \\
\hline & Woody species & 3 & 2 & 1 & & \\
\hline & Shannon Evenness Index & $2 *$ & $3 *$ & 1 & & \\
\hline & Native species & $3 *$ & $2 *$ & 1 & & \\
\hline & Wetness coefficient & 2 & 3 & 1 & & \\
\hline & Coefficient of conservatism & 3 & 2 & 1 & & \\
\hline & FQAI & 3 & 2 & 1 & & \\
\hline & FAQWet & $2 *$ & $3 *$ & 1 & & \\
\hline & Anthropogenic activity Index & 1 & 2 & 3 & & \\
\hline \multirow[t]{3}{*}{ McFarland et al. (2016) } & Herbaceous biomass & 2 & 3 & NA & Toward NAT & Yes \\
\hline & Tree biomass & 3 & 2 & NA & & \\
\hline & Tree species diversity & 3 & 2 & NA & & \\
\hline Mitchell (2016) & Mean larval species richness & $2 *$ & $3 *$ & $1 *$ & Toward NAT & Yes \\
\hline
\end{tabular}

Notes: NAT, RES, and PCC denote natural and restored wetlands, and prior converted croplands, respectively. Species richness indicates the total number of species found at each site (Yepsen et al. 2014). Woody species indicates the percentage of species found in each site characterized as woody (USDA Plants Database). Shannon Evenness Index indicates both species diversity and evenness (Gurevich et al. 2006). Wetness coefficient is indicated by the values assigned to plant species between -5 (always occurs in nonwetland upland areas) and +5 (always occurs in wetlands) (Ervin et al. 2006; Lichvar and Kartesz 2009). Coefficient of conservatism is indicated by the values assigned to plant species between 0 (nonnative or weedy species that tolerate disturbance and are found in wide variety of conditions) and 10 (native species that are only found in specific undisturbed conditions). FQAI (floristic quality assessment index) indicates site wide index based on native species richness and coefficients of conservatism (Andreas et al. 1995; Ervin et al. 2006; Lopez and Fennessy 2002). FAQWet (floristic assessment quotient for wetland) indicates site wide index based on species richness, species nativeness, and whether the species are more commonly found in wetland or upland areas (Ervin et al. 2006; Herman et al. 1997; Reed 1988). Anthropogenic Activity Index is an index for qualitatively assessing human disturbance based on observations during site visits (Ervin et al. 2006).

*Indicates no significant differences among values.

can increase bulk density, impeding root growth. Selection of restoration techniques is important to manage $\mathrm{C}$ stocks within restored wetlands.

Nitrogen $(\mathrm{N})$ values were fairly consistent among studies (table 4). PCCs had the highest $\mathrm{N}$ values among the three wetland types due to fertilizer applications, while $\mathrm{N}$ values in restored wetlands were greater than natural wetlands due to their agricultural legacy (Denver et al. 2014; Ducey et al. 2015; $\mathrm{McF}$ arland et al.2016). Note that total $\mathrm{N}$ values reported by Ducey et al. (2015) are almost identical among the three wetland types. In contrast, Hunt et al. (2014) reported greater $\mathrm{N}$ values in natural wetlands than in restored wetlands and PCCs. This inconsistent result was also found in parameters with respect to wetland denitrification processes (Hunt et al. 2014; Ducey et al. 2015). For example, denitrification enzyme activities (DEA) and denitrifying gene (nosZ) abundance between the two studies were substantially different due to distinctive soil physiochemical conditions, mineral-rich versus organic-rich soils (Hunt et al. 2014; Ducey et al. 2015).

Six of the eight studies determined that restored wetlands better supported biogeochemical functions than PCCs, and their development with time was toward natural wetlands. On the other hand, Ducey et al. (2015) stated that there was no significant improvement resulting from wetland restoration. This conclusion may be due to the short post-restoration period (4 to 7 years after restoration). Denver et al. (2014) emphasized consideration of restoration locations to efficiently capture $\mathrm{N}$-rich groundwater flow paths for improved benefits of restored wetlands for pollutant removal. For example, restored wetlands should be placed on the spot receiving water drained from upgradient croplands (Denver et al. 2014). Overall, findings support the determination that that biogeochemical functions are being improved by restored wetlands (table 4). As agricultural legacy dissipates and restored wetlands age, these improvements should be more evident.

Do Restored Wetlands Support Hydrologic Function? Unlike assessing wetland biodiversity and biogeochemical functions, the majority of studies anticipate potential hydrologic benefits of restored wetlands or document wetland hydrologic characteristics based on time-series observational data (table 5). Two studies compare three wetland types using in situ observations and geospa- tial analysis (table 6). The findings from the two studies are supportive of the conclusion that restored wetlands enhance hydrologic function (McDonough et al. 2015; Lang and McCarty 2019). Restored wetlands have surface connectivity that are close to natural wetlands (McDonough et al. 2015). A study by Lang and McCarty (2019) reveals that significant improvement in water storage capacity and associated hydrologic benefits can be attained with wetland restoration in this region.

Two wetland hydrologic functions, regulation of storm flow and surface water connectivity, were explored under the MIAR study. Water storage capacities of restored wetlands were estimated using geospatial analysis as water stored in wetlands is indicative of wetland hydrologic function associated with regulation of storm flow (Fenstermacher et al. 2014; Jones et al. 2018). Modeling results support the assertion that increased water storage capacities via wetland restoration can mitigate storm flow effects by advancing landscape hydrologic resilience in response to extreme climate events on the eastern shore of Maryland (Lee et al. 2018; Yeo et al. 2019b). Understanding of wetland connectivity (i.e., hydrologic connectiv- 


\section{Table 4}

List of biogeochemical function publications with examined biogeochemical variables, ranking of biogeochemical function, the trajectory of restored wetlands ("Direction" column), the indication of restored wetland contribution to biogeochemical function ("Contribution" column), and special notes for individual publications ("Note" column).

\begin{tabular}{|c|c|c|c|c|c|c|c|}
\hline Publication & Variables (unit) & NAT & RES & PCC & Direction & Contribution & Note† \\
\hline Church et al. (2011) & $\mathrm{P}\left(\mathrm{mg} \mathrm{kg} \mathrm{g}^{-1}\right)$ & 1 & 2 & 3 & Toward NAT & Yes & Similar to NAT \\
\hline Denver et al. (2014) & $\mathrm{NO}_{3}-\mathrm{N}\left(\mathrm{mg} \mathrm{L}^{-1}\right)$ & 1 & 2 & 3 & & No & Similar to PCC \\
\hline \multirow[t]{6}{*}{ Hunt et al. (2014) } & $\mathrm{C}(\%)$ & 3 & $2 *$ & $1 *$ & Toward NAT & Yes & Similar to PCC \\
\hline & $\mathrm{N}(\%)$ & 3 & $2 *$ & $1 *$ & & & Similar to PCC \\
\hline & $P\left(\mathrm{mg} \mathrm{kg}^{-1}\right)$ & $1^{*}$ & $2^{*}$ & 3 & & & Similar to NAT \\
\hline & Soil moisture (\%) & 3 & 2 & 1 & & & Similar to NAT \\
\hline & $\mathrm{DEA}\left(\mu \mathrm{g} \mathrm{N} \mathrm{O}_{2} \mathrm{O} \mathrm{kg}^{-1}\right.$ soil $\mathrm{h}^{-1}$ ) & 1 & 2 & 3 & & & Similar to NAT \\
\hline & nosZ gene (per g soil) & 1 & 2 & 3 & & & Between NAT and PCC \\
\hline \multirow[t]{7}{*}{ Ducey et al. (2015) } & $\mathrm{C}(\%)$ & 2 & 3 & 1 & & No & \\
\hline & $\mathrm{N}(\%)$ & $3 *$ & $2 *$ & $1 *$ & & & \\
\hline & $\mathrm{P}\left(\mathrm{mg} \mathrm{kg}^{-1}\right)$ & 1 & 2 & 3 & & & Similar to NAT \\
\hline & $\mathrm{NO}_{2}^{-}+\mathrm{NO}_{3}^{-}\left(\mathrm{mg} \mathrm{kg}^{-1}\right)$ & 1 & 2 & 3 & & & Similar to NAT \\
\hline & Soil moisture (\%) & 3 & 2 & 1 & & & Similar to NAT \\
\hline & DEA ( $\mu g \mathrm{~N}_{2} \mathrm{O}-\mathrm{N} \mathrm{kg}^{-1}$ soil h-1) & 3 & 2 & 1 & & & Similar to PCC \\
\hline & $\begin{array}{l}\text { Denitrifying gene abundance } \\
\text { (per g soil) }\end{array}$ & 2 & 1 & 3 & & & \\
\hline \multirow{2}{*}{$\begin{array}{l}\text { Fenstermacher } \\
\text { et al. (2016) }\end{array}$} & $\mathrm{C}$ (mineral-rich soils; $\mathrm{kg} \mathrm{C} \mathrm{m}^{-2}$ ) & 3 & $1 *$ & $2 *$ & Toward NAT & Yes & Similar to PCC \\
\hline & $\mathrm{C}$ (organic-rich soils; $\mathrm{kg} \mathrm{C} \mathrm{m}^{-2}$ ) & $1 *$ & 3 & $2 *$ & - & - & - \\
\hline \multirow[t]{2}{*}{ McFarland et al. (2016) } & $\mathrm{P}(\%)$ & 1 & 2 & 3 & Toward NAT & Yes & Similar to PCC \\
\hline & $\mathrm{N}(\%)$ & 1 & 2 & 3 & & & Similar to PCC \\
\hline Palardy (2018) & $\mathrm{C}\left(\mathrm{kg} \mathrm{m}^{-2}\right)$ & 3 & 2 & & Toward NAT & Yes & \\
\hline Backhaus et al. (2020) & $\mathrm{P}\left(\mathrm{mg} \mathrm{kg}^{-2}\right)$ & $2 *$ & $1 *$ & 3 & Toward NAT & Yes & Similar to NAT \\
\hline
\end{tabular}

Notes: NAT, RES, and PCC denote natural and restored wetlands, and prior converted croplands, respectively. DEA indicates Denitrification Enzyme Activity. nosZ gene is one denitrification gene responsible for converting nitrous oxide $\left(\mathrm{N}_{2} \mathrm{O}\right)$ to $\mathrm{N}_{2} \cdot \mathrm{P}=$ phosphorus. $\mathrm{NO}_{3}-\mathrm{N}=$ nitrate-nitrogen. $\mathrm{N}=$ nitrogen. $\mathrm{C}=$ carbon. $\mathrm{NO}_{2}-\mathrm{N}=$ nitrite-nitrogen.

*Indicates no significant differences among values.

†This column indicates whether examined variables are closer to natural wetlands, PCCs, or between natural wetland and PCCs.

ity between wetlands and surface waters) is crucial to protect, improve, and maintain ecosystem services granted by wetlands. Under the MIAR study, wetland connection with nearby streams was investigated using a state data logger in the field (McDonough et al. 2015) and a LiDAR-DEM at landscape levels (Lang et al. 2012).

A wetland monitoring network implemented by the MIAR study observed informative wetland hydrologic characteristics. Lee et al. (2019a) compared temporal changes in wetland hydrology at two sites with and without a low-permeability soil layer. This comparison indicated that a low-permeability soil layer limits water infiltration as well as groundwater contribution to wetland water balance (Lee et al. 2019a). Lee et al. (2020a) documented that similar behaviors between wetlands and downstream waters exist due to strong climatic seasonality and dissimilar ones may be driven by wetland fill-spill dynamics and differences in

\section{Table 5}

List of hydrologic function publications with examined hydrologic characteristics and quantitative tools for individual publications.

\begin{tabular}{lll}
\hline Publication & $\begin{array}{l}\text { Wetland hydrologic function } \\
\text { and characteristics }\end{array}$ & Tool* \\
\hline Lang et al. (2012) & Wetland surface water connectivity & GA \\
Fenstermacher et al. (2014) & Wetland water storage capacity & GA \\
McDonough et al. (2015) & Wetland surface water connectivity & In situ observations \\
Jones et al. (2018) & Wetland water storage capacity & GA \\
Lee et al. (2018) & Increased watershed resilience & HM \\
Yeo et al. (2019b) & Increased watershed resilience & HM \\
Lang and McCarty (2019) & Wetland water storage capacity & GA \\
Lee et al. (2019a) & Wetland-groundwater interaction & In situ observations \\
Lee et al. (2020a) & Drivers of wetland hydrologic dynamics & In situ observations \\
\hline *GA and HM denote geospatial analysis and hydrologic modeling, respectively. In situ observa- \\
tions report wetland hydrologic characteristics based on measurements.
\end{tabular}

recession rates between wetland water levels and downstream flows.

Overall, hydrologic functions were most frequently investigated using various quantita- tive approaches in the MIAR study. However, direct comparisons among three wetland types were limited relative to other functions since landscape-level studies that include all 
Table 6

List of hydrologic function publications with examined hydrologic variables, ranking of hydrologic function, and the indication of restored wetland contribution to biogeochemical function ("Contribution" column) for individual publications.

\begin{tabular}{llllll}
\hline Functions & Descriptions & NAT & RES & PCC & Contribution \\
\hline McDonough et al. (2015) & Cumulative connection duration & 3 & $2^{*}$ & $1^{*}$ & Yes \\
Lang and McCarty (2019) & Median volume storage & $2^{*}$ & $1^{*}$ & $3^{*}$ & Yes \\
\hline
\end{tabular}

Note: NAT, RES, and PCC denote natural and restored wetlands, and prior converted cropland, respectively.

*Indicates no significant differences among values.

wetland types were commonly executed. A few comparative studies indicated that restored wetlands contribute to regulating storm flow and increasing connectivity with downstream waters, resulting in improved hydrologic function. Increases in the number or size of restored wetlands were found to be beneficial for landscape hydrology.

Tool Development: Remote Sensing Technique. MIAR efforts focused on use of remotely sensed data for wetland mapping at the landscape scale (table 7). Forested wetlands are abundant in this region, but monitoring those wetlands is challenging due to the tree canopy (Lang et al. 2015b). To efficiently detect the extent of wetlands under tree covers, LiDAR data have been widely used for monitoring. Lang and McCarty (2009) succeeded in mapping wetland inundation using LiDAR intensity data, and validation results indicate $96 \%$ overall accuracy. Lang et al. (2020) employed a normalized LiDAR intensity data to improve wetland inundation mapping in area with evergreen vegetation with overall accuracy of $99.4 \%$ to $100 \%$. Topographic wetness indices derived from LiDAR-DEMs can also be used to map wetlands and predict the likelihood of inundation at a landscape scale (Lang et al. 2013). The fusion of LiDAR intensity and Landsat 30 meter multispectral data allowed the generation of time-series wetland inundation maps across the landscape (Huang et al. 2014). A recent study by Du et al. (2020) demonstrated the suitability of deep neural networks to accurately map forested wetland inundation in the MIAR.

Remote sensing data are important by themselves, but their usefulness can be amplified when integrated with in situ data, hydrologic modeling, and geospatial analysis. Detailed examples are provided in the hydrologic modeling and geospatial analysis sections. The diversity and availability of remotely sensed data are rapidly increasing and will play a significant role in future conservation practices. In particular, individual or multiple wetlands exhibit different functions depending on locations, and thus,

\section{Table 7}

List of publications adopting remote sensing techniques with final products and input data used for individual publications.

\begin{tabular}{|c|c|c|}
\hline Publication & Remote sensing products & Input data \\
\hline Lang and McCarty (2009) & Mapping forest wetland inundation & LiDAR intensity \\
\hline Lang et al. (2013) & Mapping forest wetland inundation & $\begin{array}{l}\text { LiDAR-based } \\
\text { topographic metrics }\end{array}$ \\
\hline Huang et al. (2014) & Inundation map & Landsat and LiDAR intensity \\
\hline Jin et al. (2017) & Inundation map & Landsat and LiDAR intensity \\
\hline Du et al. (2020) & Mapping forest wetland inundation & $\begin{array}{l}\text { World view, LiDAR, } \\
\text { and topographic metrics }\end{array}$ \\
\hline Lang et al. (2020) & Mapping forest wetland inundation & Normalized LiDAR intensity \\
\hline
\end{tabular}

remote sensing data can deliver valuable information about ecosystem services gained from wetland restoration at plot and landscape levels of observation. Remote sensing data can help us understand historical trends of wetland disturbances or enhancements. Further details about wetland remote sensing applications are available in Lang et al (2015a and 2015c). Hence, remotely sensed data provide significant insights on wetland ecosystem services, which will be critical for the MIAR study.

Tool Development: Hydrologic Modeling. The Soil and Water Assessment Tool (SWAT) model has been intensively utilized to explore watershed-level wetland functions under the MIAR study (table 8). A plot-scale modeling study was also conducted using SWAT, as well as the Agricultural Policy/ Environmental eXtender (APEX) model. The MIAR study supported hydrologic modeling tool development through model algorithm improvement, integration of new wetland modules, and use of remotely sensed data. These improvements resulted in advanced simulation of wetland hydrologic and biogeochemical processes. The most challenging aspect of modelling is often the minimization of predictive uncertainty stemming from model input data, parameters, structure, and outputs (Beven 2006; Renard et al. 2010; Hublart et al. 2015; Højberg and Refsgaard 2005). Modeling assessments under the MIAR study focused on not only advancing model capacity, but also reducing predictive uncertainty.

Sharifi et al. (2016) modified SWAT to set spatialized denitrification potentials across the landscape for enhanced representation of biogeochemical wetland function. Evenson et al. (2018) improved SWAT's capacity to simulate wetland interactions with surrounding areas, as well as upgradient/downgradient wetlands at the watershed level. Lee et al. (2018) incorporated enhanced wetland modules into SWAT for enhanced representation of riparian and geographically isolated wetlands' hydrologic processes at the landscape scale. Lee et al. (2019b) improved SWAT model predictions of watershed-level wetland inundation on the floodplain area by incorporating a wetland map developed from remote sensing data into model parameterization. Qi et al. (2019) enabled SWAT to accurately predict water level dynamics of individual wetlands through source code modification. Wetland biogeochemical cycling within APEX was also improved by Sharifi et al. (2019). Nutrient transformation accounts for a key part of wetland biogeochemical processes, but hydrologic models generally disregard these complex nutrient transformations, and nutrient removal is instead simulated by deposition, regardless of incoming nutrient types. Sharifi et al. (2019) incorporated the biogeochemical WetQual 
Table 8

List of publications adopting hydrologic modeling approaches, including type of model, development process applied, wetland function, and spatial scales.

\begin{tabular}{|c|c|c|c|c|}
\hline Publication & Model & Development & Ecosystem function* & Spatial scale $†$ \\
\hline Sharifi et al. (2016) & SWAT & Algorithm improvement & $B G$ & Watershed \\
\hline Evenson et al. (2018) & SWAT & Algorithm improvement & HD & Watershed \\
\hline Lee et al. (2018) & SWAT & Integration of new wetland modules & HD & Watershed \\
\hline Lee et al. (2019b) & SWAT & $\begin{array}{l}\text { Integration of new wetland modules; } \\
\text { use of remotely sensed data for parameterization }\end{array}$ & HD & Watershed \\
\hline Sharifi et al. (2019) & APEX & Algorithm improvement & $B G$ & Plot \\
\hline Qi et al. (2019) & SWAT & Algorithm improvement & HD & Plot \\
\hline Yeo et al. (2019b) & SWAT & Integration of new wetland modules & HD & Watershed \\
\hline Lee et al. (2020b) & SWAT & $\begin{array}{l}\text { Integration of new wetland modules; } \\
\text { structural uncertainty evaluation }\end{array}$ & HD & Watershed \\
\hline
\end{tabular}

*BG and HD indicate biogeochemical and hydrologic functions.

†Plot indicates individual wetlands (Sharifi et al. [2019]: one ancillary restored wetland, and Qi et al. [2019]: two core natural wetlands and two core restored wetlands). A watershed in the spatial scale column indicates the boundary defined by hydrologic unit code (HUC).

module (Hantush et al. 2012) into APEX, and this incorporation enabled APEX to realistically simulate $\mathrm{N}$ and $\mathrm{P}$ cycling.

Uses of in situ observations and remote sensing data as validation data were also shown to improve model predictions of wetland hydrology (Evenson et al. 2018; Qi et al. 2019). Under the MIAR study, available in situ observations and landscape-level estimates of land surface hydrologic parameters are increasing. These datasets will provide opportunities for wetland modelers to increase model accuracy while reducing predictive uncertainty. However, all remotely sensed data contain uncertainty. Therefore, this potential uncertainty should be carefully stated in order to determine the appropriate use of those data in hydrologic modeling. Incomplete representation of environmental processes within a hydrologic model is one source of uncertainty (Yen et al. 2014). Oversimplification of physical processes and limited model frameworks (i.e., semidistributed model) may increase this uncertainty. Advances in wetland model structures undertaken under the MIAR study address model structural uncertainty to some degree. A recent study finds that structural uncertainty of wetland modeling can be reduced with a spatial model structure (Lee et al. 2020b). Ongoing MIAR modeling studies are focused on structural improvement addressing varying wetland processes at individual locations.

Although predictive uncertainty always exists, a major advantage of hydrologic models is that they can be used to quantify changes in the provision of ecosystem services due to wetland restoration practices. Model improvement has been a key part of the MIAR study, and this supports the improved quantification of the effects and effectiveness of wetland restorations. Ongoing wetland monitoring using in situ observation and remotely sensed data and efforts to improve model algorithms should lead to development of even more reliable modeling tools. These tools can be used to quantify wetland functions and ecosystem services from restored wetlands at multiple spatial scales.

Tool Development: Geospatial Analysis. The MIAR study used various geospatial analyses to explore wetland hydrologic, biogeochemical, and landscape characteristics relevant to wetland restoration and conservation (table 9). Geospatial analysis tools were advanced mostly as a result of improved high-resolution land surface information derived from remote sensing data. LiDARderived DEMs were extensively employed in geospatial analysis to explore (1) surface water connectivity between wetlands and streams (Lang et al. 2012); (2) geomorphic characteristics of wetlands that support wetland conservation and management (Fenstermacher et al. 2014); (3) spatial variability of wetland denitrification potential over the landscape (Ator et al. 2013; Li et al. 2018); and (4) estimation of wetland water storage capacity (Jones et al. 2018; Lang and McCarty 2019). Yeo et al. (2019a) characterized wetland inundation dynamics and their relationship with downstream flow using remote sensing-derived wetland inundation maps developed by Huang et al. (2014) and Jin et al. (2017).

Backhaus et al. (2020) developed a remote wetland functional assessment tool by combining hydrogeomorphic characteristics (e.g., landscape position, landform, water flow path and waterbody type) and the National
Wetland Inventory geospatial dataset. This tool can assign wetland functions and performance to individual wetlands, by assessing wetland biodiversity, biogeochemical, and hydrologic functional indicators (Backhaus et al. 2020).

By characterizing spatial heterogeneity across landscapes, geospatial analysis can help to identify key wetland landscape parameters, supporting site-specific wetland restoration plans. In addition, estimated landscape parameters from geospatial analysis can be used as "soft data" to help parameterize hydrologic models that lack direct observations. Improved techniques to map topographic parameters and increased availability of remote sensing-derived maps will lead to increased usefulness and reliability of geospatial analysis for the MIAR study.

Discussion. The individual projects that compose the larger MIAR study have resulted in findings that can be used to best guide implementation of wetland restorations in the MIAR, but additional insights are gained through the synthesis of these studies. One key finding of this regional study is that populations of flora and fauna associated with restored wetlands in the region were slow to change toward the natural forested wetland condition (Yepsen et al. 2014; Mitchell et al. 2016). This may be due to unique ecosystem stressors, such as increased soil compaction associated with the restoration process inhibiting certain plant populations, or management decisions by the landowner, such as mowing the wetland buffer to prevent development of woody species populations (Yepsen et al. 2014). These altered wetland states can add to biodiversity of the landscape by providing alternative habitats for both flora and fauna. Whether such altered states 


\section{Table 9}

List of publications that adopted geospatial analysis tools and analyzed wetland characteristics with list of wetland functions for individual publications.

\begin{tabular}{|c|c|c|}
\hline Publication & Analyzed wetland characteristics & Wetland function* \\
\hline Lang et al. (2012) & $\begin{array}{l}\text { Surface water connectivity between } \\
\text { wetlands and streams }\end{array}$ & $\mathrm{HD}$ \\
\hline Ator et al. (2013) & $\begin{array}{l}\text { Wetland denitrification potential by } \\
\text { landscape characteristics }\end{array}$ & $B G$ \\
\hline Fenstermacher et al. (2014) & $\begin{array}{l}\text { Wetland geomorphology and } \\
\text { abundance across the landscape }\end{array}$ & - \\
\hline Jones et al. (2018) & $\begin{array}{l}\text { Wetland water storage capacity } \\
\text { estimation }\end{array}$ & $\mathrm{HD}$ \\
\hline Li et al. (2018) & $\begin{array}{l}\text { Wetland denitrification potential } \\
\text { prediction based on topographic } \\
\text { characteristics }\end{array}$ & $B G$ \\
\hline Yeo et al. (2019a) & $\begin{array}{l}\text { Relation of wetland inundation } \\
\text { dynamics with streamflow }\end{array}$ & $\mathrm{HD}$ \\
\hline Lang and McCarty (2019) & $\begin{array}{l}\text { Wetland water storage capacity } \\
\text { estimation }\end{array}$ & $H D$ \\
\hline Backhaus et al. (2020) & $\begin{array}{l}\text { Combination of landscape level } \\
\text { data and individual National } \\
\text { Wetland Inventory wetlands }\end{array}$ & $\mathrm{BD}, \mathrm{BC}$, and $\mathrm{HD}$ \\
\hline
\end{tabular}

*BD, BG, and HD indicate biodiversity, biogeochemical, and hydrologic functions.

are positive or negative environmental endpoints is debatable.

Restored wetlands may provide enhanced or unique ecosystem services important for human transformed landscapes. As an example, the common adjacency of restored wetlands to sites of agricultural production is likely to enhance nutrient mitigation services relative to that of natural wetlands due to their high potential to receive agricultural nutrients (Denver et al.2014). Denitrification in natural wetlands was often constrained by limited nitrate $\left(\mathrm{NO}_{3}^{-}\right)$, while restored wetlands may rarely experience $\mathrm{NO}_{3}^{-}$limitation due to agricultural legacy and adjacency (Hunt et al. 2014; Ducey et al. 2015). Tradeoffs between ecosystem services should also be considered. A restored wetland may harbor nutrient loving invasive species such as cattail (Typha spp.), which may enhance nutrient processing but be detrimental to ecosystem biodiversity (USEPA 2002). A restored wetland may provide better conditions for amphibian larvae sensitive to water $\mathrm{pH}$ than natural wetlands due to remaining liming effects (Mitchell 2016).

Regardless, efforts toward natural states have beneficial impacts on the ability of wetlands to support a wide array of ecosystem services. For example, McDonough et al. (2015) found that natural wetlands had a greater potential to support the hydrologic, ecologic, and biogeochemical integrity of downstream waters due to their stronger hydrologic connection relative to restored wetlands (McDonough et al. 2015). In addition, natural wetlands supported water quality through the support of relatively low nutrient waters (Church et al. 2011) Findings from the MIAR study support the assertion that restored and natural wetlands provide beneficial services, but the level of service provided often depends on the type of ecosystem functions being considered. Thus, the baseline condition for wetland restoration (i.e., the ecosystem target) should be set to enhance specific ecosystem services that are necessary for a watershed or region.

A finding that restored wetlands by design or by default may not replace ecosystem services provided by lost natural wetlands increases the need to maintain or enhance remaining natural wetlands within a landscape. Altered working landscapes and more generally the dominant influence of humans on terrestrial ecosystems reflects the now increasingly recognized emerging geological epoch of the Anthropocene, and this influence is not likely to decrease.

\section{Summary and Conclusions}

This paper synthesizes findings from assessments conducted over the past 10 years under the MIAR study to help determine whether restored wetlands provide ecosystem functions that are similar to natural wetlands, and to characterize the potential of various wetland monitoring and assess- ment tools that were developed as part of the MIAR study. Our overview of MIAR publications reveals that biodiversity, biogeochemical, and hydrologic functions of restored wetlands developed via USDA conservation programs are closer to those shown in natural wetlands relative to PCCs. However, the trajectory is not consistent amongst studies. Remote sensing, hydrologic modeling, and geospatial analysis tools have been advanced as part of the MIAR study, and those tools contribute to mapping the extent of wetland inundation across landscapes, quantifying wetland hydrologic and biogeochemical benefits at the multiple scales, and identifying important landscape parameters affecting wetland functions. Findings from the MIAR study addressed specific actions for land managers to promote current positive trends and support wetland conservation practices for enhanced provision of wetland-related ecosystem services. These findings include the following:

1. Establishment of long-term easements should be permitted to provide time for slow succession processes, including plant succession, soil organic C accumulation, and development of more natural soil biogeochemistry.

2. Activities that increase soil compaction should be constrained to generate conditions conducive to root growth and the transport of $\mathrm{NO}_{3}^{-}$rich groundwater from agricultural lands into wetland soils with high $\mathrm{NO}_{3}^{-}$removal potentials.

3. Enhanced capacity of wetland restoration to regulate water transport and mitigate flooding can be better attained by increasing either individual wetland cell number or size.

4. Conservation of natural wetlands should receive high priority and become part of overall wetland restoration/maintenance plans because of their provision of unique ecosystem services as well as their synergic impacts on nearby restored wetlands and PCCs by encouraging development of natural species and assisting $\mathrm{NO}_{3}{ }^{-}$removal.

5. Wetland restoration should be preferably undertaken on low-elevation locations relative to broader-scale topographic gradients for increased interception of agricultural pollutants from up-gradient areas.

6. Shallow water and gently sloping topographies should be considered in design of wetland basins as those can reproduce 
hydrologic attributes (e.g., hydroperiod and water depth) of natural wetlands, leading to colonization and growth of plant species that are representative of more natural conditions.

7. Spatial heterogeneity of landscape parameters, including topographic, geologic, and climatic properties should be taken into account when targeting, implementing, and managing wetland conservation practices since those parameters have substantial impact on ecosystem service provision resulting from wetland restoration.

8. Regarding advances in geospatial data acquisition and analysis techniques over the past decade, geospatial datasets and techniques should be used for implementing and managing precision conservation practices to improve ecosystem service provision and the determination of derived benefits at a landscape scale.

\section{Acknowledgements}

This work was supported by the USDA Natural Resources Conservation Service in association with the Wetland Component of the National Conservation Effects Assessment Project, the USDA National Institute of Food and Agriculture (2017-67003-26484 and 2017-67003-26485), and the National Aeronautics and Space Administration Terrestrial Ecology Program (NNX17AE66G).

\section{Disclaimer}

USDA is an equal opportunity provider, employer, and lender. Any use of trade, firm, or product names is for descriptive purposes only and does not imply endorsement by the US Government. The findings and conclusions in this article are those of the author(s) and do not necessarily represent the views of the US Fish and Wildlife Service.

\section{References}

Andreas, B.K., and R. Lichvar. 1995. Floristic index for establishing assessment standards: A case study for Northern Ohio. Wetlands Research Program Technical Report WRP-DE-8.Vicksburg, MS: US Army Engineer Waterways Experiment Station.

Ator, S.W., J.M. Denver, A.E. LaMotte, and A.J. Sekellick. 2013. A regional classification of the effectiveness of depressional wetlands at mitigating nitrogen transport to surface waters in the Northern Atlantic Coastal Plain. Reston, VA: US Department of the Interior, US Geological Survey.

Backhaus, J.P., Q.M. Nassry, S. Lee, G.W.McCarty, M.W.Lang, and P.R. Brooks. 2020. Evaluating a remote wetland functional assessment along an alternation gradient in coastal plain depressional wetlands. Journal of Soil and Water Conservation doi:10.2489/jswc.2020.00094.

Barbier, L. 2013. Valuing ecosystem services for coastal wetland protection and restoration: Progress and challenges. Resources 2(3):213-230.

Beven, K. 2006. A manifesto for the equifinality thesis. Journal of Hydrology 320(1-2):18-36.

Bullock, A., and M. Acreman. 2003. The role of wetlands in the hydrological cycle. Hydrology and Earth System Sciences 7(3):358-389.

Church, C.D., P.J.A. Kleinman, and J.O. Miller. 2011. Trends in soil phosphorus in native, disturbed, and hydrologically restored agricultural wetlands. Abstract. Proceedings of the Soil and Water Conservation Society summer 2011 meeting, Washington, DC, July 17-20, 2011.

Cvetkovic, M., and P. Chow-Fraser. 2011. Use of ecological indicators to assess the quality of Great Lakes coastal wetlands. Ecological Indicators 11(6):1609-1622.

Denver, J.M., S.W. Ator, M.W. Lang, T.R. Fisher, A.B. Gustafson, R. Fox, J.W. Clune, and G.W. McCarty. 2014. Nitrate fate and transport through current and former depressional wetlands in an agricultural landscape, Choptank Watershed, Maryland, United States. Journal of Soil and Water Conservation 69(1):1-16. https://doi. org/10.2489/jswc.69.1.1.

Du, L., G.W. McCarty, X. Zhang, M.W. Lang, M.K. Vanderhoof, X. Li, C. Huang, S. Lee, and Z. Zou. 2020. Mapping forested wetland inundation in the Delmarva Peninsula, USA, using deep convolution neural networks. Remote Sensing (12)4:644.

Ducey, T.F., J.O. Miller, M.W. Lang, A.A. Szogi, P.G. Hunt, D.E. Fenstermacher, M.C. Rabenhorst, and G.W. McCarty. 2015. Soil physicochemical conditions, denitrification rates, and nosZ abundance in North Carolina Coastal Plain restored wetlands. Journal of Environmental Quality 44 (3):1011-1022.

Ervin, G.N., B.D. Herman, J.T. Bried, and D.C. Holly. 2006. Evaluating non-native species and wetland indicator status as components of wetlands floristic assessment. Wetlands 26:1114-1129.

Evenson, G.R., C.N. Jones, D.L. McLaughlin, H.E. Golden, C.R. Lane, B. DeVries, L.C.Alexander, M.W. Lang, G.W. McCarty, and A. Sharifi. 2018. A watershed-scale model for depressional wetland-rich landscapes. Journal of Hydrology X 1:100002.

Fenstermacher, D.E., M.C. Rabenhorst, M.W. Lang, G.W. McCarty, and B.A. Needelman. 2014. Distribution, morphometry, and land use of Delmarva Bays. Wetlands 34(6):1219-1228.

Fenstermacher, D.E., M.C. Rabenhorst, M.W. Lang, G.W. McCarty, and B.A. Needelman. 2016. Carbon in natural, cultivated, and restored depressional wetlands in the mid-Atlantic coastal plain. Journal of Environmental Quality 45(2):743-750.

Fisher, J., and M. Acreman. 2004. Wetland nutrient removal: A review of the evidence. Hydrology and Earth System Sciences 8(4):673-685.
Gurevich, J., S.M. Scheiner, and G.A. Fox. 2006. The Ecology of Plants. Sunderland, MA: Sinauer.

Hantush, M.M., L. Kalin, S. Isik, and A. Yucekaya. 2013. Nutrient dynamics in flooded wetlands. I: Model development. Journal of Hydrologic Engineering 18(12):1709-1723.

Herman, K.D., A.A. Reznicek, L.A. Masters, G.S. Wilhelm, M.R. Penskar, and W.W. Brodowicz. 1997. Floristic quality assessment: Development and application in the state of Michigan (USA). Natural Areas Journal 17: 265-279.

Højberg, A.L., and J.C. Refsgaard. 2005. Model uncertaintyparameter uncertainty versus conceptual models. Water Science \& Technology 52(6):177-186.

Huang, C., Y. Peng, M. Lang, I.Y.Yeo, and G. McCarty. 2014. Wetland inundation mapping and change monitoring using Landsat and airborne LiDAR data. Remote Sensing of Environment 141:231-242.

Hublart, P., D. Ruelland, A. Dezetter, and H. Jourde. 2015. Reducing structural uncertainty in conceptual hydrological modelling in the semi-arid Andes. Hydrology and Earth System Sciences 19(5):2295-2314.

Hunt, P.G., J.O. Miller, T.F. Ducey, M.W. Lang, A.A. Szogi, and G. McCarty. 2014. Denitrification in soils of hydrologically restored wetlands relative to natural and converted wetlands in the Mid-Atlantic coastal plain of the USA. Ecological Engineering 71:438-447.

Jin, H., C. Huang, M.W. Lang, I.Y. Yeo, and S.V. Stehman. 2017. Monitoring of wetland inundation dynamics in the Delmarva Peninsula using Landsat time-series imagery from 1985 to 2011. Remote Sensing of Environment 190:26-41.

Jones, C.N., G.R. Evenson, D.L. McLaughlin, M.K. Vanderhoof, M.W. Lang, G.W. McCarty, H.E. Golden, C.R. Lane, and L.C. Alexander. 2018. Estimating restorable wetland water storage at landscape scales. Hydrological Processes 32(2):305-313.

Lang, M., L. Bourgeau-Chavez, R. Tiner, and V. Klemas. 2015a. Advances in remotely sensed data and techniques for wetland mapping and monitoring. In Remote Sensing of Wetlands: Applications and Advances, eds. R. Tiner, M. Lang, and V. Klemas, 79-116. Boca Raton, FL: CRC Press.

Lang, M., V. Kim, G.W. McCarty, X. Li, I.Y.Yeo, C. Huang, and L. Du. 2020. Improved detection of inundation below the forest canopy using normalized LiDAR intenstidy data. Remote Sensing (12)4:707.

Lang, M.W., and G.W. McCarty. 2009. Lidar intensity for improved detection of inundation below the forest canopy. Wetlands 29(4):1166-1178.

Lang, M., and G.W. McCarty. 2019. Depressional Wetland water storage volume on the Delmarva Peninsula. USDA NRCS Conservation Effects Assessment Project Science Note, 1-8. Washington, DC: USDA Natural Resources Conservation Service.

Lang, M., G. McCarty, T. Ducey, P. Hunt, J. Miller, M. Rabenhorst, A. Baldwin, D. Fenstermacher, M. Yepse, E. 
McFarland, A. Sharifi, C. Church, J. Denver, S. Ator, J. Mitchell, D. Whigham, and M. Walbridge. 2015b. Effects and Effectiveness of USDA Wetland Convervation Practice in the Mid-Altantic Region: A Report on the Conversation Effects Assessment Project Mid-Atlantic Regional Wetland Assessment 2008-2015. Washington, DC: USDA Natural Resources Conservation Service.

Lang, M., G.W. McCarty, O. McDonough, R. Oesterling, and W. Wilen. 2012. Enhanced detection of wetland-stream connectivity using LiDAR. Wetlands 32:461-473.

Lang, M.W., G.W. McCarty, R. Oesterling, and I.Y.Yeo. 2013. Topographic metrics for improved mapping of forested wetlands. Wetlands 33(1):141-155.

Lang, M., S. Purkis, V. Klemas, and R. Tiner. 2015c. Promising developments and ruture challenges for remote sensing of wetlands. In Remote Sensing of Wetlands: Applications and Advances, eds. R. Tiner, M. Lang, andV. Klemas, 533-544. Boca Raton, FL: CRC Press.

Lee, S., G. McCarty, G. Moglen, M. Lang, C.N. Jones, M. Palmer, A.M. Sadeghi, I.-Y Yeo, M. Anderson, A.M Sadeghi, and M.C. Rabenhorst. 2020a. Seasonal drivers of geographically isolated wetland (GIW) hydrology in a low-gradient, coastal plain landscape. Journal of Hydrology 583:124608.

Lee, S., G.W. McCarty, G.E. Moglen, M.W. Lang, A.M. Sadeghi, T.R. Green, I.Y. Yeo, and M.C. Rabenhorst. 2019a. Effects of subsurface soil characteristics on wetland-groundwater interaction in the coastal plain of the Chesapeake Bay watershed. Hydrological Processes 33(2):305-315.

Lee, S., H. Yen, I.-Y. Yeo, G.E. Moglen, M.C. Rabenhorst, and G.W. McCarty. 2020b. Use of multiple modules and Bayesian Model Averaging to assess structural uncertainty of catchment-scale wetland modeling in a Coastal Plain landscape. Journal of Hydrology 582:124544.

Lee, S., I.-Y. Yeo, W.M. Lang, W.G. McCarty, A.M. Sadeghi, A. Sharifi, H. Jin, and Y. Liu. 2019b. Improving the catchment scale wetland modeling using remotely sensed data. Environmental Modelling \& Software 12:104069.

Lee, S., I.Y. Yeo, M.W. Lang, A.M. Sadeghi, G.W. McCarty, G.E. Moglen, and G.R. Evenson. 2018. Assessing the cumulative impacts of geographically isolated wetlands on watershed hydrology using the SWAT model coupled with improved wetland modules. Journal of Environmental Management 223:37-48.

Li, X., G.W. McCarty, M.W. Lang, T. Ducey, P. Hunt, and J. Miller. 2018. Topographic and physicochemical controls on soil denitrification in prior converted croplands located on the Delmarva Peninsula, USA. Geoderma 309:41-49.

Lichvar, R.W., and J.T. Kartesz. 2009. North American Digital Flora: National Wetland Plant List, version 2.4.0. Hanover, NH, and Chapel Hill, NC: US Army Corps of Engineers, Engineer Research and Development Center, Cold Regions Research and Engineering Laboratory, and BONAP. https://wetland_plants.usace.army.mil.
Lopez, R.D., and M.S. Fennessy. 2002. Testing the floristic quality assessment index as an indicator of wetland condition. Ecological Applications 12:487-497.

McDonough, O.T., M.W. Lang, J.D. Hosen, and M.A. Palmer. 2015. Surface hydrologic connectivity between Delmarva Bay wetlands and nearby streams along a gradient of agricultural alteration. Wetlands 35(1):41-530

McFarland, E.K., M. LaForgia, M. Yepsen, D.F. Whigham, A.H. Baldwin, and M.W. Lang. 2016. Plant biomass and nutrients $(\mathrm{C}, \mathrm{N}$ and $\mathrm{P})$ in natural, restored and prior converted depressional wetlands in the Mid-Atlantic Coastal Plain, US. Folia Geobotanica 51(3):267-283.

Meli, P., J.M.R. Benayas, P. Balvanera, and M.M. Ramos. 2014. Restoration enhances wetland biodiversity and ecosystem service supply, but results are contextdependent:A meta-analysis. PloS one 9(4):e93507.

Mitchell, J.C. 2016. Restored wetlands in mid-Atlantic agricultural landscapes enhance species richness of amphibian assemblages. Journal of Fish and Wildlife Management 7(2):490-498.

Palardy, C.A. 2018. Impact of Restoration Activity on Wetland Soil Properties and Functions. Ph.D dissertation, University of Maryland.

Qi, J., X. Zhang, S. Lee, G.E. Moglen, A.M. Sadeghi, and G.W. McCarty. 2019. A coupled surface water storage and subsurface water dynamics model in SWAT for characterizing hydroperiod of geographically isolated wetlands. Advances in Water Resources 131:1033810.

Reed, P.B. 1988. National List of Plant Species That Occur in Wetlands: 1988 National Summary. Washington, DC: US Fish and Wildlife Service.

Renard, B., D. Kavetski, G. Kuczera, M. Thyer, and S.W. Franks. 2010. Understanding predictive uncertainty in hydrologic modeling:The challenge of identifying input and structural errors. Water Resources Research 46(5):W05521.

Sharifi, A., M.W. Lang, G.W. McCarty, M.A. Sadeghi, S. Lee, H.Yen, J. Jeong, and M.C. Rabenhorst. 2016. Improving model prediction reliability through enhanced representation of wetland soil processes and constrained model auto calibration - A paired watershed study. Journal of Hydrology 541:1088-1103.

Sharifi, A., S. Lee, G.W. McCarty, M.W. Lang, J. Jeong, A.M. Sadeghi, and M.C. Rabenhorst. 2019. Enhancement of Agricultural Policy/Environment eXtender Model (APEX) Model to assess effectiveness of wetland water quality functions. Water 11(3):606.

USDA NRCS (USDA Natural Resources Conservation Service). 2010. Conservation Practice Standard Wetland Restoration. https://www.nrcs.usda.gov/Internet/FSE_ DOCUMENTS/nrcs143_026340.pdf.

USEPA (US Evrionmental Protection Agency). 2002 Methods for Evaluating Wetland Condition:VegetationBased Indicators of Wetland Nutrient Enrichment. Washington, DC: Office of Water, US Environmental Protection Agency.

Yen, H., R.T. Bailey, M.Arabi, M.Ahmadi, M.J.White, and J.G. Arnold. 2014. The role of interior watershed processe in improving parameter estimation and performance of watershed models. Journal of Environmental Quality 43(5):1601-1613.

Yeo, I.-Y., M.W. Lang, S. Lee, G.W. McCarty, A.M. Sadeghi, O. Yetemen, and C. Huang. 2019a. Mapping the landscape-level hydrologic connectivity of headwater wetlands to downstream water: A geospatial modelling approach - Part I. Science of the Total Environment 653:1546-1556.

Yeo, I.-Y., S. Lee, M.W. Lang, O. Yetemen, G.W. McCarty, A.M. Sadeghi, and G. Evenson. 2019b. Mapping the landscape-level hydrologic connectivity of headwater wetlands to downstream water: a geospatial modelling approach - Part 2. Science of the Total Environment $653: 1557-1570$

Yepsen, M., A.H. Baldwin, D.F. Whigham, E. McFarland, M. LaForgia, and M. Lang. 2014. Agricultural wetland restorations on the USA Atlantic Coastal Plain achieve diverse native wetland plant communities but differ from natural wetlands. Agriculture, Ecosystems, and Environment 197:11-20.

Zedler, J.B., and S. Kercher. 2005. Wetland resources: Status, trends, ecosystem services, and restorability. Annual Review of Environment and Resources 30:39-74.

Zhao, Q., J. Bai, L. Huang, B. Gu, Q. Lu, and Z. Gao. 2016. A review of methodologies and success indicators for coastal wetland restoration. Ecological Indicators 60:442-452. 